"local tradition" in the different populations of $R$. auritus as reported by Ellis, Wiens \& Rodell (1976).

Acknowledgements: Authors wish to express their gratitude towards: Dr. Osvaldo A. Reig for suggestions and reading the manuscript, to Jorge Orbea, Andrea Clausen and Leopoldo Montes for their help in identification of plant specimens and to Silvia Cid for her help in the identification of epidermal plant fragments. Thanks are also due to Daniel Periz and the late Miguel Sánchez for his valuable help in the field work.

\title{
REFERENCES
}

Barlow J. C., 1966: Observations on the biology of rodents in Uruguay. Life Sci. Contr. R. Ont. Mus., 75: 1-59. - Cauhepe M. A. \& Fernandez Grecco R., 1981: Dieta de vacunos en pastoreo en un pastizal natural de la Depresión del Saldo. Prod. Animal., 8: (in press). - Ellis J. E., Wiens J. A., Rodell C. F. \& Anway J. C., 1976: A conceptual model of diet selection as an ecosystem process. J. theoret. Biol., 60: 93-108. - Fraker S. B. \& Brischle J. A., 1944: Measuring the local distribution of Ribes. Ecology, 25: 283-303. - Harris L. D. \& Paur L. F., 1972: US/IBP Grassland Biome Tech. Rep. No 154. Fort Collins; Colorado State University. - Hershkovitz P., 1975: South American marshrats, genus Holochilus, with a summary of Sigmodon rodents. Fieldiana Zool., 32: 639-687. - Herrera C. M., 1976: A trophic diversity index for presence-absence food data. Oecologia (Berl.) 25: 187-191. - Leon R. J. C., 1975: Las comunidades herbáceas de la región Castelli-Pila. La Plata, Argentina. Comisión de Investigaciones Cientificas. pp. 73-107 (Monografias N. 5). - Scaglia O. A., Velazquez C. A. \& Cauhepe M. A., 1981: Técnica de microanálisis para estudio de dieta en herbivoros. Prod. Animal (Argentina), 7: 572-576. - Stritmatter C., 1973: Nueva técnica de diafanización. Sociedad Argentina de Botánica. Boletin 15: 126-129. - Williamson J., 1940: Plaga poco conocida entre los agriculores, "el ratón conejo". Granos (Argentina), 4 (78): 31 .

Accepted, January 29, 1982.

\section{Cranial and Dental Abnormalities in Sika Deer}

\author{
ANOMALIE KOSCI CZASZKI I ZĘBOW U JELENIA SIKA
}

George A. FELDHAMER

Feldhamer G. A., 1982: Cranial and dental abnormalities in sika deer. Acta theriol., 27, 24: 353-357 [With 1 Table \& Plates VIII-IX]

Cranial and dental abnormalities are described from sika deer, Cervus nippon (Temminck, 1836). Congenital (intrinsic) abnormalities occurred in only 4 of 191 specimens $(2.1 \%)$. Abnormalities that resulted from extrinsic factors included alveolar thinning, noted in $33(18.3 \%)$ of the specimens, and periodontal disease, found in $2(1.0 \%)$ specimens.

[Appalachian Environmental Laboratory, Center for Environmental and Estuarine Studies, University of Maryland, Frostburg State College Campus, Gunter Hall, Frostburg, Maryland 21532, USA] 


\section{INTRODUCTION}

Abnormalities of the skull and dentition have been described for numerous mammalian species, including many species of cervids. Such anomalies as brachygnathism, agenesis and supernumeration have been noted for white-tailed deer, Odocoileus virginianus (Zimmermann, 1780) and mule deer, $O$. hemionus (Rafinesque, 1817) by several investigators (Robinette, 1958 ; Ryel, 1963 ; Short, 1964 ; and others). Similar anomalies have been described for other cervids, including red deer, Cervus elaphus (Linnaeus, 1758) (Mayer, 1977; 1978), fallow deer, Cervus dama (Linnaeus, 1758) (Chapman \& Chapman, 1969), caribou, Rangifer tarandus (Linnaeus, 1758) (Miller \& Tessier, 1971), and roe deer, Capreolus capreolus (Linnaeus, 1758) (Meyer, 1975). There is little, if any, published information, however, on cranial and dental abnormalities in sika deer, Cervus nippon (Temminck, 1836), despite the widespread distribution of this species by introductions throughout the last century. This paper deals with cranial and dental abnormalities found in an introduced population of sika deer from Dorchester County, Maryland, USA.

\section{METHODS AND MATERIALS}

The sample was comprised of 191 complete skulls collected at check-stations and hunting camps in Dorchester County, Maryland, during the deer hunting seasons in 1977-1979. All skulls were cleaned by boiling and examined for the following abnormalities: plagiocephaly - asymmetrical cranial growth caused by premature closure of one frontal-parietal suture; bregmatic bones - an extra bone derived from accessory ossification of any of the fontanelles; heterotopic bones - small, accessory bones; supernumeration - teeth in excess of the usual number; congenital agenesis - a reduced dental complement because teeth failed to develop; ir regular placement - teeth in positions other than normal, and a lve olar thinning - the exposure of the buccal tooth roots. Also, the lacrimal orifices of the skulls were examined for differences in size, shape or position among individuals. Finally, all skulls were examined for the loss of dental material because of periodontal disease. Age classes of deer were determined by the wear and eruption of dentition as described by Lowe (1967) for red deer and Duff (1969) for sika deer.

\section{RESULTS AND DISCUSSION}

The sex and age composition of deer in the sample is given in Table 1. Sika deer calves, which are dropped in the spring (May to June) were approximately six months of age when collections were made during the hunting season (late November to early December). Pedicles of male calves had not developed by this time, and the sex of calves could not be ascertained from skulls. Calves probably were collected in a $1: 1$ ratio, however. Significantly more adult females than males were represented in the sample $\left(\chi^{2}=32.9, P<0.001\right)$, because hunters were reluctant to give up heads of males with well-developed antlers. Conversely, yearling bucks, which from only spike antlers, were represented signific- 
antly more in the sample than were yearling females $\left(\chi^{2}=5.71, P<0.025\right)$ These sampling biases had no affect on the observed results, however.

Cranial and dental abnormalities found in the sample are discussed according to whether they were believed to be intrinsic (systemic) or extrinsic (local) in origin.

Intrinsic Origin. In sika deer, as in other cervids, the normal position of the two lacrimal orifices is on the anterior rim of the eye orbit, one above the other, with the lower orifice slightly anterior. On the skulls examined, the position of the orifices was somewhat variable, and the lower orifice occasionally was narrowed in shape. However, on two

\section{Table 1}

The number of sika deer (Cervus nippon) skulls in each sex and age category from Dorchester County, Maryland, examined for cranial and dental anomalies.

\begin{tabular}{lccc}
\hline Sex & $\begin{array}{c}\text { Calves }^{a} \\
\text { Age Class }^{\text {0) }}\end{array}$ & $\begin{array}{c}\text { Yearlings } \\
\text { (Age class 1) }\end{array}$ & $\begin{array}{c}\text { Adults } \\
\text { (Age Class 2+) }\end{array}$ \\
\hline Male & - & 45 & 15 \\
Female & - & 25 & 67 \\
Unknown & 39 & 0 & 0 \\
\hline
\end{tabular}

a The sex of calves could not be determined from skulls.

skulls $(1 \%$ of the sample) the lower orifice on one side was slit-like and displaced about $8 \mathrm{~mm}$ anterior to the orbital rim (Fig. 1, Plate VIII). There was no evidence of previous injury. In both specimens, the orifices on the other side were normal. In their review of the lacrimal orifices in a variety of ruminants, Leinders \& Heitz (1980) reported anomalies in only 5 of 172 skulls $\left(2.9^{\circ} \%\right)$ of cervids examined. Their sample contained only two sika deer, both of which were normal.

Irregular placement involving maxillary premolars was apparent in two specimens $(1.0 \%$ ). In a 2-year old female, the last premolar on the left side was rotated lingually 90 degrees so that the cups were perpendicular to the tooth row. The other two premolars also were slightly rotated. On the right side, the second premolar was rotated and displaced posteriolingually ; the third premolar was rotated and displaced anteriolabially (Fig. 2). In a 6-year old female, the second premolar on the right side was rotated lingually about 20 degrees. In both specimens, there was no apparent traumatic injury, infection, impaction or loss of underlying bone. Colyer (1936) described position variations in eight other genera of deer that also occurred exclusively in the premolars. He felt this was because permanent premolars erupt after the molars, and the forward movement of the molars may leave reduced space for the premolars. Although exact sample sizes were not always given, Colyer (1936 : 373) found a "limited number" of positional variations in approximately 300 deer skulls.

No cases of plagiocephaly, heterotopic bones or bregmatic bones were found in the 191 sika deer skulls examined.

Likewise, no instances of supernumeration or agenesis were noted in the 152 adults and yearlings. These anomalies were not considered for 
the molariform dentition of calves, however, as the second and third molars in each quadrant were not erupted. These anomalies were considered for yearlings, however, as the alveolus of $\mathrm{M} 3$, and often the unerupted tooth, were evident. In all samples, the alveoli of the maxillary canines were present. These teeth are loosely socketed, however, and were often lost in the process of cleaning the skulls.

Although supernumeration and agenesis have been described for many species of deer (see Miller \& Tessier, 1971), these variations are rare when considered on a percentage basis. For example, maxillary canine teeth were reported in only 23 of 18,000 white-tailed deer $(0.1 \%)$ in New York (Van Gelder \& Hoffmeister, 1953). Supernumeration occurred in only 13 of 1,226 caribou $\left(1.1^{1 \%}\right.$ ) (Miller \& Tessier, 1971). Pekelharing (1968) found an additional molar in only 1 of 580 red deer $(0.2 \%)$ and 1 of 130 wapiti $(0.8 \%)$ in New Zealand. Similarly low percentages of occurrence have been reported for agenesis in large samples of whitetailed deer (Free et al., 1972; Mech et al., 1970).

Extrinsic Origin. Alveolar thinning in the sika deer skulls examined was associated only with he molariform teeth. It occurred in 33 skulls $(18.3 \%) ; 2$ calves, 19 yearlings and 12 adults. In almost all cases, alveolar thinning was slight. Smith et al. (1977) felt that alveolar thinning resulted from internal pressures during mastication, with no associated pathology. The preponderance of older-aged sika deer with alveolar thinning supports this view.

Peridontal disorders were found in $1 \%$ of the sample-a 9 -year old female (Fig. 3A) and a 6-year old female (Fig. 3B). There is a direct correlation between periodontia and age in humans, and this condition also is generally found in older wild animals (Robinson, 1979). Both local and systemic causes of periodontal disease in humans have been summarized by Grainger (1968) and Orban (1967). Many of these causes are not applicable to species other than man. In wild animals, periodontal disease probably is caused by extrinsic factors such as food penetrating the soft tissues during mastication or by chemical products of impacted food that destroy the epithelial surface and lead to deeper infection (Colyer, 1936). Peridontal disorders are more common in captive than in wild cervids.

In the sika deer population in Maryland, the low incidence of abnormalities of an intrinsic origin may to a certain extent be associated with the very low degree of genetic heterozygosity in the herd. Feldhamer et al. (in press) found no polymorphism in 10 enzymes from liver and muscle tissue from this population. This was attributed to the small number of sika deer originally introduced in Maryland (Flyger, 1960) and a resultant "founder effect". This low incidence of abnormalities in the introduced sika deer population may be contrasted to the high incidence of congenital agenesis $(16.7 \%$ ) found in the molariform dentition of native white-tailed deer from Dorchester County (Feldhamer \& Chapman, 1980).

Generally, the incidence of congenital skull anomalies is relatively low in cervids (Colyer, 1936; Pekelharing, 1968). The results of this study support this generalization. Congenital abnormalities that are seriously maladaptive probably predispose individuals to prenatal or 
neonatal mortality. Thus, animals with such anomalies are rarely available for study. Conversely, sika deer with the cranial or dental abnormalities described here, and noted for other species of cervids, probably are adversely affected to only a minor degree, if at all.

Acknowledgements: W. Bruce Taliaferro and numerous students from the Appalachian Envirnmental Laboratory aided in the collection of skulls. Numerous hunting clubs from Dorchester County were most cooperative in this project, including the 10-4 Club and other organizations. This research was supported as part of a contract from the Maryland Wildlife Administration to the Appalachian Environmental Laboratory. This is Contribution No. 1311-AEL, Appalachian Environmental Laboratory, Center for Environmental and Esturine Studies. University of Maryland and Federal Aid to Wildlife Restoration W-49-R to Maryland.

\section{REFERENCES}

Chapman D. I. \& Chapman N. G., 1969: The incidence of congenital abnormalities in the mandibular dentition of fallow deer (Dama dama L.). Res. Vet. Sci., 10: 485-487. - Colyer F., 1936: Variations and diseases of the teeth of animals. John Bale, Sons and Danielsson, Ltd: 1-750. London. - Duff K. R., 1969: Tooth eruption as a guide to ageing Japanese sika deer (Cervus nippon) in Dorset. Deer, 2: 566-567. - Feldhamer G. A. \& Chapman J. A., 1980: Mandibular dental anomaly in white-tailed deer. Brimleyana, 4: 161-163. - Feldhamer G. A., Morgan R. P., Mckeown P. E. \& Chapman J. A., (in press): Lack of polymorphism in liver and muscle enzymes from sika deer (Cervus nippon). J. Mammal. - Flyger V., 1960: Sika deer on islands in Maryland and Virginia. J. Mammal. 41: 140. - Free S. L., Bergstrom A. S. \& Tanck J. E., 1972: Mandibular and dental anomalies of whitetailed deer. N.Y. Fish Game J., 19: 32-46. - Grainger R. M., 1978: Problems in the clinical trial of agents for control of periodontal disease. Ann. New York Acad. Sci., 153: 288-306. - Leinders J. J. M. \& Heintz E., 1980: The configuration of the lacrimal orifices in Pecorans and Tragulids (Artiodactyla, Mammalia) and its significance for the distinction between Bovidae and Cervidae. Beaufortia, 30: 155-162. - Lowe V. P. W., 1967: Teeth as indicators of age with special reference to red deer (Cervus elaphus) of known age from Rhum. J. Zool. (London), 152: 137-153. - Mech L. D., Frenzel L. D., Jr., Karns P. D. \& Kuehn D. W., 1970: Mandibular dental anomalies in white-tailed deer from Minnesota. J. Mammal., 51: 804-806. - Meyer V. P., 1975: Beispiele angeborener Zahn- und Gebissanomalien beim Europäischen Reh (Capreolus capreolus Linne, 1958) nebst einigen Bemerkungen $\mathrm{zu}$ deren Genese und Terminologie. Z. Jagdwiss., 21: 89-105. Meyer V. P., 1977: Anomalie der Nasenbeine beim Rothirsch (Cervus elaphus L.). Z. Jagdwiss., 23: 92-94. - Meyer V. P., 1978: Zahnmissibildung bei einem Rothirsch (Cervus elaphus L.). Z. Jagdwiss., 24: 45-47. - Miller F. L. \& Tesiser G. D., 1971: Dental anomalies in caribou, Rangifer tarandus. J. Mammal., 52: 164-174. Orban B., 1967: Classification and nomenclature of periodontal disease. Pp. $1-7$. [In: A. J. Lazare (ed.), "Peridontal therapy: A review "]. New York Univ. Press, New York. - Pekelharing C. J., 1968: Molar duplication in red deer and wapiti. J. Mammal., 49: 524-526. - Robinette W. L., 1958: Unusual dentition in mule deer. J. Mammal., 39: 156-157. - Robinson P. T., 1979: A literature review of dental pathology and aging by dental means in nondomestic animals, Parts I \& II. J. Zoo. An. Med., 10: 57-65; 81-91. - Ryel L. A., 1963: The occurrence of certain anomalies in Michigan white-tailed deer. J. Mammal., 44: 79-98. Short H. L., 1964: Notes and comments on mandibular malformations in deer. J. Mammal., 45: 319-321. - Smith J. D., Genoways H. H. \& Jones J. K., Jr., 1977: Cranial and dental anomalies in three species of Platyrrhine monkeys from Nicaragua. Folia Primatol, 28: 1-42. - Van Gelder R. G., \& Hoffmeister D. F., 1953: Canine teeth in white-tailed deer. J. Wildl. Manage., 17: 100.

Accepted, December 24, 1981. 